\title{
Dampak Penerapan GMP dan SSOP terhadap Kualitas Minuman Kunyit Asam SMUD SMK Muhammadiyah 2 Malang
}

\author{
Warkoyo $^{1}$, Damat ${ }^{2}$, Sri Winarsih ${ }^{3}$ \\ 1, 2, 3 Prodi Ilmu dan Teknologi Pangan, Fakultas Pertanian Petenakan, \\ 1,2,3 Universitas Muhammadiyah Malang \\ e-mail: ${ }^{1}$ warkoyo@umm.c.id, ${ }^{2}$ damatumm@gmail.com, ${ }^{3}$ sriwinarsih@umm.ac.id
}

\begin{abstract}
Abstrak
Di Malang dan sekitarnya pertumbuhan UMKM yang memproduksi minuman berasa dalam kemasan semakin banyak dikarenakan permintaan produk ini juga semakin banyak. Produk minuman dalam kemasan yang beredar di Malang yang khas adalah sari apel, temulawak, sari buah jambu, sinom dan kunyit asam. SMK Muhammadiyah 2 juga mengambil peran dalam pemenuhan permintaan minuman dalam kemasan yaitu kunyit asam. SMK Muhammadiyah 2 Malang memiliki unit usaha minuman kunyit asam dalam kemasan. Proses produksi minuman kunyit asam ini masih belum menerapkan sistem GMP dan SSOP yang baik. Tujuan dari kegiatan ini adalah mensosialisasikan tenatng sistem GMP dan SSOP agar mutu minuman meningkat. Metode yang digunakan untuk pendampingan ini adalah tutorial dan pendampingan penerapan GMP dan SSOP kepada staff yang berperan aktif dalam produksi minuman kunyit asam dan mampu meningkatkan mutu produk yang sesuai dengan SNI 01-4320-1996.
\end{abstract}

Kata kunci : GMP; SSOP; kunyit asam

\begin{abstract}
In Malang and surrounding areas was growth home industry that produce beverages to supply demand of beverage product, was increased as people increased. The beverage products sale in Malang are apple juice, ginger juice, guava juice, sinom and tamarindus-turmeric drink (kunyit asam). SMK Muhamadiyah 2 Malang also takes part in fulfilling the demand of beverage, his product is turmeric acid. The process for producing the turmeric drink still has not implemented a good GMP and SSOP system. The purpose are introduce GMP and SSOP System, it can improve the quality of turmeric drink. The methods are teaching about GMP and SSOP system also coaching the worker about skill on application GMP and SSOP system. The result the programs coaching the turmeric drink quality suitable with SNI 01-4320-1996.
\end{abstract}

Keywords : GMP; SSOP; tamarindus-turmeric drink 


\section{PENDAHULUAN}

Produk minuman dalam kemasan merupakan produk yang populer di masyarakat dan bervariasi bahan bakunya, menyesuaikan selera konsumen. Produk minuman dalam kemasan yang beredar di Malang yang khas adalah sari apel, temulawak, sari buah jambu, sinom dan kunyit asam. Minuman dalam kemasan memiliki kelebihan praktis mudah penyajiannya, sesuai dengan tuntutan masyarakat pada sekarang yang menginginkan produk instan.

Di Malang dan sekitarnya pertumbuhan UMKM yang memproduksi minuman berasa dalam kemasan semakin banyak dikarenakan permintaan produk ini juga semakin banyak. Usaha menengah kecil dan mikro dapat menjadi salah satu tulang punggung perekonomian nasional. Pada tahun 2014 kontribusi UMKM terhadap perekonomian mencapai 57\% dari total Produk Domestik Bruto. Pada sisi ekspor kontribusi UMKM mencapai $16 \%$ dari total ekspor yang telah dilakukan oleh Indonesia di tahun 2014. Hal tersebut semakin memperkuat pendapat bahwa UMKM dapat menjadi salah satu tulang punggung perekonomian dan mampu bersaing di dunia Internasional.

SMK Muhammadiyah 2 juga mengambil peran dalam pemenuhan permintaan minuman dalam kemasan yaitu kunyit asam. Sekolah ini memiliki unit usaha minuman kunyit asam dalam kemasan,yang sudah memulai produksi sejak tahun 2016, dengan kapasitas produksi menyesuaikan dengan pesanan. Produk kunyit asam yang diproduksi unit usaha produk yang dihasilkan dari sekolah cukup disukai konsumen, dengan banyaknya pesanan yang masuk apalagi ketika menjelang hari raya. Dari hasil diskusi dengan kepala unit produksi bahwa produksi minuman kunyit asam ini masih memiliki kendala yaitu masa simpan yang pendek hanya 2 hari saja. Dari hasil diskusi tersebut maka dirasa perlu adanya pengabdian Universitas Muhammadiyah Malang untuk memperbaiki kualitas dan memperpanjang masa minuman kunyit asam yang diproduksi amal usaha Muhammadiyah.

\section{SUMBER INSPIRASI}

Unit usaha kecil, menengah maupun besar yang bergerak dalam bidang pangan sebaiknya senantiasa mengarahkan kegiatan usahanya untuk menghasilkan produk yang memenuhi standar keamanan pangan serta memberikan kepuasan bagi konsumen. Masalah keamanan pangan pada saat ini sedang mendapatkan perhatian penuh dari pemerintah, serta menjadi sebuah tuntutan yang harus dipenuhi oleh setiap perusahaan yang bergerak dalam bidang pangan. Hal ini disebabkan oleh semakin meningkatnya minat konsumen terhadap produk yang bernilai Aman, Sehat, Utuh dan Halal (ASUH).

Pemenuhan produk yang bernilai ASUH dapat dilakukan dengan menerapkan Good Manufacturing Practices (GMP) dan Sanitation Standard Operating Procedures (SSOP) pada keseluruhan rangkaian proses produksi yang berlangsung

Hasil survey lokasi dan wawancara dengan ketua unit usaha minuman kunyit asam didapatkan hasil bahwa mitra telah memiliki formulasi produk yang disukai oleh konsumen, namun setelah di produksi dalam jumlah besar ada permasalahan bahwa masa simpan produk hanya dua hari pada penyimpanan suhu ruang, Dari hasil diskusi tersebut maka dirasa perlu adanya pengabdian Universitas Muhammadiyah Malang untuk memperbaiki kualitas dan memperpanjang masa minuman kunyit asam yang diproduksi amal usaha Muhammadiyah.

Adapun program yang ingin berikan kepada mitra adalah sosialisasi dan penerapan SSOP dan GMP yang dirasa masih belum dikenal dan diterapkan oleh mitra, sehingga program ini diharapkan bermanfaat untuk mitra dalam upaya meningkatkan kualitas produk.

\section{METODE KEGIATAN}

Tahapan persiapan pelaksanaan program dilakukan pada bulan pertama sesuai dengan rancangan kegiatan yang disusun, dengan cara menjalin komunikasi dengan mitra untuk menentukan jadwal perlaksaan program, mengidentifikasi jumlah peserta yang akan dilibatkan 
dalam kegiatan, penyusunanmateri yang akan di berikan dalam kegiatan pengabdian dan mempersiapkan alat dan bahan penunjang kegiatan pengabdian.

Program pengabdian akan dilaksanakan setelah tahapan persiapan telah selesai, pelaksanaan program pengabdian meliputi :

1. Penyuluhan tentang Sistem SSOP dan GMP

Metode sosialisasi atau penyuluhan dilakukan terhadap staff dan siswa siswi yang perperan dalam proses produksi minuman kunyit asam .

2. Pendampingan penerapan kedua sistem

Dengan metode ini diharapkan akan mengubah tata cara produksi pangan ke arah yang lebih baik sehingga mendapatkan kualitas dan masa simpan produk yang lebih baik lagi sehingga perlu diberikan pengenalan tentang GMP dan SSOP serta pendampingan penerapannya. Metode yang digunakan dalam kegiatan ini adalah tutorial pengenalan mengenai sistem GMP dan SSOP serta pendampingan dan konsultasi terkait penerapan kedua sistem terhadap staf yang bekerja untuk unit produksi minuman kunyit asam dan beberapa siswa siswi yang secara bergilir membantu kegiatan produksi. Setelah diberikan penyuluhan dan pendampingan, satu bulan berikutnya diambil sampel minuman kunyit asam untuk diuji kualitas secara kimia dan mikrobiologi serta disimpan selama 1 bulan untuk melihat daya simpan produk, yang berkaitan dengan kerusakan yang disebabkan oleh mikroorganisme yang ditandai dengan penggembungan minuman kunyit asam.

\section{KARYA UTAMA}

Penerapan kelayakan dasar, yaitu cara berproduksi yang baik dan besar atau atau Good Manufacturing Practice (GMP) dan standar sanitasi atau Sanitation Standard Operating Procedures (SSOP). Kedua sistem perlu dilakukan pada semua jenis usaha makanan dan minuman baik modern maupun tradisional. Pada pengolahan pangan sistem manajemen mutu yang efektif dapat menjamin mutu dan keamanan produk. Penerapan sanitasi membahas pemeliharaan umum bangunan atau fasilitas usaha, bahan yang digunakan untuk pembersihan atau sanitasi, pengendalian hama, sanitasi permukaan, penyimpanan dan penanganan peralatan serta tempat [5]. Cara berproduksi yang baik dan benar terdiri dari berbagai macam persyaratan yang secara umum meliputi: persyaratan mutu dan keamanan bahan baku/bahan pembantu, persyaratan penanganan bahan baku/bahan pembantu, persyaratan pengolahan, persyaratan pengemasan produk, persyaratan penyimpanan produk dan persyaratan distribusi produk. Persyaratan persyaratan tersebut dapat dijabarkan lebih spesifik lagi sesuai dengan jenis produk yang diolah.

\section{ULASAN KARYA}

Penerapan sistem GMP dan SSOP pada mitra masih belum maksimal (Tabel 1 dan 2).

Tabel 1. Penerapan GMP oleh mitra

\begin{tabular}{|c|c|c|}
\hline No & Parameter & $\begin{array}{l}\text { Tingkat Penerapan sebelum } \\
\text { kegiatan }\end{array}$ \\
\hline 1 & $\begin{array}{l}\text { Lokasi dan } \\
\text { Lingkungan }\end{array}$ & $\begin{array}{l}\text { - Bebas banjir, polusi asap, belum bebas } \\
\text { debu, bau, dan kontaminan lain. } \\
\text { - Tidak bebas dari sarang hama seperti } \\
\text { hewan pengerat dan serangga. } \\
\text { - Tidak berada dekat industri logam dan } \\
\text { kimia, pembuangan sampah atau } \\
\text { Limbah }\end{array}$ \\
\hline 2 & $\begin{array}{l}\text { Bangunan dan } \\
\text { fasilitas usaha }\end{array}$ & $\begin{array}{l}\text { - Desain, konstruksi dan tata ruang } \\
\text { belum sesuai dengan alur proses dan } \\
\text { masih bercampur dengan proses dari } \\
\text { unit lain. } \\
\text { - Bangunan tidak luas untuk dapat } \\
\text { melakukan pembersihan secara } \\
\text { intensif. } \\
\text { - Lantai terbuat dari bahan yang kedap } \\
\text { air, namun dinding terbuat dari batu } \\
\text { bata yang lembab, lantai mudah } \\
\text { dibersihkan, serta sudut pertemuannya } \\
\text { tidak berbentuk lengkung. } \\
\text { - Tidak ada gudang penyimpanan }\end{array}$ \\
\hline
\end{tabular}

Tabel 2. Penerapan Sistem Sanitasi oleh Mitra

\begin{tabular}{|c|l|l|}
\hline No & \multicolumn{1}{|c|}{ Parameter } & Tingkat Penerapan sebelum kegiatan \\
\hline 1 & $\begin{array}{l}\text { Keamanan Air } \\
\text { untuk Proses }\end{array}$ & $\begin{array}{l}\text { Air digunakan } \\
\text { menggunakan air PDAM }\end{array}$ \\
\hline 2 & $\begin{array}{l}\text { Kondisi dan } \\
\text { kebersihan } \\
\text { permukaan yang } \\
\text { kontak langsung } \\
\text { dengan produk }\end{array}$ & $\begin{array}{l}\text { Permukaan yang kontak dengan } \\
\text { bahan bersih dan disanitasi. } \\
\text { - Lantai, peralatan bersih } \\
\text { - Karyawan tidak memakai sarung } \\
\text { tangan }\end{array}$ \\
\hline 3 & $\begin{array}{l}\text { Pencegahan } \\
\text { Kontaminasi Silang }\end{array}$ & $\begin{array}{l}\text { - Karyawan tidak menggunakan } \\
\text { tutup kepala, sarung tangan (ganti } \\
\text { sesuai kebutuhan) dan masih } \\
\text { memakai perhiasan. }\end{array}$ \\
& & $\begin{array}{l}\text { Karyawan masih belum tertib } \\
\text { mencuci tangan sebelum } \\
\text { pekerjaan dimulai. }\end{array}$ \\
\hline
\end{tabular}




\section{KESIMPULAN}

Sistem GMP dan SSOP masih telah dilaksanakan dengan baik oleh Mitra (SMK 2 Muhammadiyah Malang) yang berdampak pada peningkatan mutu dan daya simpan minuman kunyit asam bisa bertahan (tidak mengalami penggembungan) selama 3 bulan.

\section{DAMPAK DAN MANFAAT KEGIATAN}

Dari uraian Tabel 1 dan 2 maka upaya untuk memberikan edukasi kepada mitra dilakukan, yaitu dengan memberikan penyuluhan tentang pengenalan dan penerapan GMP dan SSOP untuk industri.

Kegiatan ini disambut antusias oleh siswa dan guru SMK Muhammadiyah 2. Ditandai dengan berkembang ke arah diskusi yang membahas tentang kondisi riil tempat produksi yang kurang memenuhi syarat GMP maupun SSOP, demikian juga untuk proses produksi yang sudah dilakukan selama ini. Suasana penyuluan sebagaimana dapat dilihat pada Gambar 1.

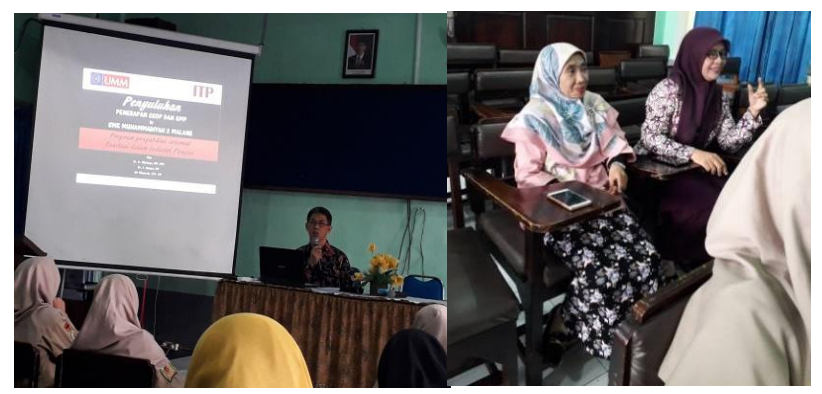

Gambar 1. Penyuluhan Pengenalan dan penerapan GMP dan SSOP

Setelah penyuluhan, tim pengabdi masih melakukan pendampingan terhadap mitra dalam menerapkan GMP dan SSOP sesuai dengan kondisi rill keberadaan sarana proasaran produksi yang telah dimiliki. Kegiatan pendampingan sebagaimana tampak pada Gambar 2 . Salah satu dampak yang ditimbulkan karena tidak diterapkan sistem GMP dan sanitasi yang baik adalah pendeknya daya simpan produk minuman kunyit asam. Minuman kunyit asam yang diproduksi sering mengalami kerusakan setelah disimpan selama 2 hari, dengan ciri-ciri terjadi penggembungan pada kemasan.

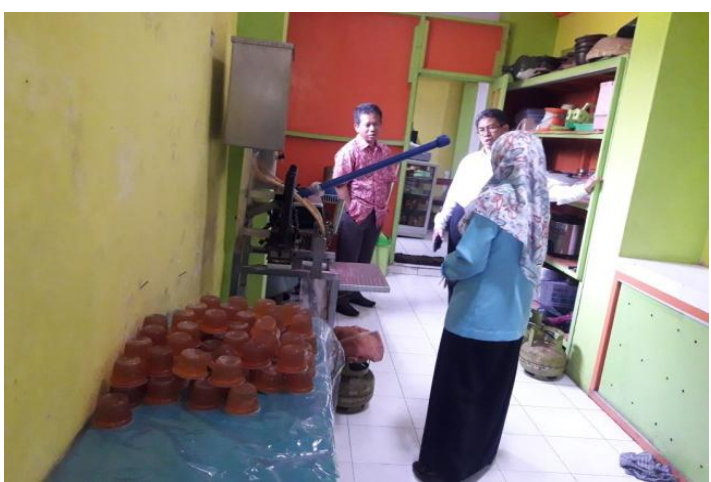

Gambar 2. Kegiatan Pendampingan Mitra dalam menerapkan sistem GMP dan SSOP

Setelah pemberian penyuluhan, mitra didampingi dalam menerapkan GMP dan SSOP. Hasil penerapan GMP dan SSOP memberikan dampak yang baik terhadap kualitas produk, serta peningkatan umur simpan produk. Produk dapat bertahan hingga 3 bulan pada penyimpanan suhu ruang.. Produk kunyit asam ditampilkan pada Gambar 3.

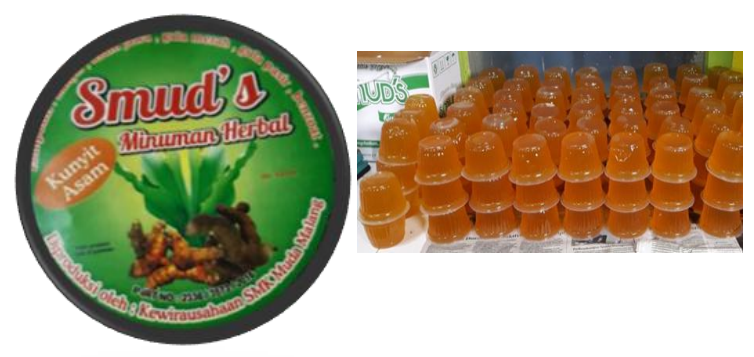

Gambar 3. Logo dan Produk Muniman Kunyit Asam

Produk yang disimpan selama 3 bulan diuji di Laboratorium ilmu dan Teknologi Pangan UMM untuk melihat kualitas fisik, kimia maupun mikrobiologi, hasil analisis menunjukkan kualitas produk yang baik, sebagaimana ditampilkan pada Tabel 3.

Tabel 3. Karakteristik Fisik, Kimia dan Mikrobiologi Minuman Kunyit Asam

\begin{tabular}{|l|c|}
\hline \multicolumn{1}{|c|}{ Parameter } & Jumlah \\
\hline TPT ( ${ }^{\circ}$ Briks) & 11 \\
pH & 4,3 \\
Tingkat Kekuningan $(\mathrm{b}+)$ & 4,7 \\
Tingkat Kemerahan $(\mathrm{a}+)$ & 0,5 \\
Total asam Tertitrasi $(\%)$ & 3,18 \\
Vitamin C $(\%)$ & 0,149 \\
TPC $(\mathrm{cfu} / \mathrm{ml})$ & $1 \times 10^{2}$ \\
Aktivitas antioksidan $(\mathrm{IC} 50)(\mu / \mathrm{mL})$ & 123,78 \\
\hline
\end{tabular}


Dari Tabel 3 menunjukkan bahwa kualitas minuman kunyit asam secara fisik, kimia dan mikrobiologi telah memenuhi SNI untuk minuman tradisional. SNI yang digunakan untuk membandingkan produk minuman kunyit asam ini adalah minuman serbuk tradisional, [3] minuman serbuk tradisional adalah Serbuk Minuman Tradisional adalah produk bahan minuman berbentuk serbuk atau granula yang dibuat dari campuran gula dan rempah-rempah dengan atau tanpa penambahan bahan makanan lain dan bahan tambahan makanan yang diizinkan. SNI ini digunakan sebagai pendekatan mutu minuman kunyit asam yang terbuat dari rempahkunyit dan asam dan ditambakan dengan gula pasir dan pengawet $\mathrm{Na}$ Benzoat dengan kadar dibawah ambang batas Permenkes No 722/MENKES/PER/IX/1988. Hanya saja ada perbedaan bentuk yaitu produk minuman kunyit asem ini berbentuk cair siap minum. Dari hasil uji laboratorium menunjukkan bahwa produk minuman kunyit asem ini memiliki mutu yang baik dengan penambahan pemanis gula pasir tanpa pemanis sintetis, hasil uji menunjukkan kadar sakarosa yang teritung sebagai tota padatan terlarut sebesar $11^{\circ}$ Brik atau setara dengan jumlah sakarosa $11 \%$. Hasil uji pH 4,3 didukung dengan analisis total asam tertitrasi merupakan penciri minuman kunyit asam yang berasa asam dengan keasaman yang masih bisa diterima oleh konsumen. Keasaman pada produk ini sekaligus mampu menyeleksi mikrobia yang dapat mengkontaminasi produk ini, hal ini terbukti dengan jumlah total mikrobia (TPC) sebesar $1 \times 10^{2} \mathrm{cfu} / \mathrm{ml}$. Nilai TPC minuman kunyit tidak melampui standar SNI yaitu sebesar $3 \times 10^{3} \mathrm{cfu} / \mathrm{ml}$.

Kelebihan lain dari produk ini adalah kandungan vitamin C sebesar $0,149 \%$ yang bisa mensuplay kebutuhan vitamin bagi konsumennya, sekaligus menyumbang antioksidan dalam tubuh. Hasil uji antioksidan pada produk menggunakan IC50 menunjukkan bahwa minuman ini memiliki nilai IC50 sebesar 123,78 $\mu \mathrm{g} / \mathrm{mL}$, dari klasifikasi kakuatan antioksidan maka minuman kunyit asam ini memiliki kekuatan antioksidan kategori sedang. [1] Tingkat kekuatan antioksidan adalah sangat kuat bila harga IC50 $<50 \mu \mathrm{g} / \mathrm{mL}$; kuat bila harga IC50 50-100 $\mu \mathrm{g} / \mathrm{mL}$; sedang bila harga IC50 101-150 $\mu \mathrm{g} / \mathrm{mL}$; dan lemah bila harga IC $50>150 \mu \mathrm{g} / \mathrm{mL}$. Semakin kecil harga IC 50, maka semakin besar daya peredamannya.

Uraian diatas menunjukkan bahwa minuman kunyit asam ini merupakan minuman fungsional, karena dapat meredam radikal dalam tubuh. [2] Senyawa antioksidan yang berada pada minuman kunyit asam adalah golongan flavonoid, flavanoid telah banyak dibuktikan oleh para peneliti mampu menurunkan gula darah atau mencegah penyakit diabetes millitus. Penyakit diabetes militus disebabkan oleh rusaknya sel-sel penghasil insulin. Proses kerusakan sel ini dapat dinetralisis oleh senyawa antioksidan yang berasalal dari flavonoid. [4] Ekstrak kunyit-buah asam mempunyai kemampuan menghambat terbentuknya malonaldehid (MDA) pada proses oksidasi lemak. Senyawa ini merupakan salah satu produk hasil dari oksidasi lemak pada membran sel didalam tubuh.

\section{DAFTAR PUSTAKA}

[1] Blois, M.S. 1958. Antioxidant determinations by the use of a stable free radical. Nature, 181:1199-1200.

[2] Mulyani, S; B. Admadi, H. dan Diah P.GAK. 2011. Potensi Minuman Kunyit Asam (Curcuma domestica Val.- Tamarindus indica L.) sebagai Penurun Gula Darah Pada Tikus Hiperglikemik. Laporan Hibah Bersaing, Universitas Udayana.

[3] SNI 01-4320-1996. Minuman Serbuk Tradisional. Badan Standarisasi Nasional.

[4] Suwariani and Suhendra, L. 2008. Sinergisme Aktivitas Antioksidan Kunyit-Asam (Curcuma domestica Val.-Tamarindus indica L.) Sebagai Penangkap Radikal Bebas. Seminar Nasional Pengembangan Agroindustri Berbasis Sumber Pangan Lokal untuk Peningkatan Kedaulatan Pangan, Yogyakarta. 
[5] Winarno, F.G dan Surono. 2004. GMP Cara Pengolahan Pangan Yang Baik. M-Brio Press. Bogor.

\section{PENGHARGAAN}

Kami sampaikan ucapan terimakasih kepada Universitas Muhammadiyah Malang yang telah mendanai pengabdian ini, melalui program PPMI. 